\title{
Biochar Based Inoculants Improve Soybean Growth and Nodulation
}

\author{
Martyna Głodowska', Timothy Schwinghamer ${ }^{1}$, Barry Husk ${ }^{2}$, Donald Smith ${ }^{1}$ \\ ${ }^{1}$ Department of Plant Science, McGill University, Macdonald Campus, Sainte-Anne-de-Bellevue, Canada \\ ${ }^{2}$ BlueLeaf Inc., Drummondville, Canada \\ Email: martyna.glodowska@mail.mcgill.ca
}

How to cite this paper: Głodowska, M., Schwinghamer, T., Husk, B. and Smith, D. (2017) Biochar Based Inoculants Improve Soybean Growth and Nodulation. Agricultural Sciences, 8, 1048-1064.

https://doi.org/10.4236/as.2017.89076

Received: August 23, 2017

Accepted: September 25, 2017

Published: September 28, 2017

Copyright (c) 2017 by authors and Scientific Research Publishing Inc. This work is licensed under the Creative Commons Attribution International License (CC BY 4.0).

http://creativecommons.org/licenses/by/4.0/

cc) (i) Open Access

\begin{abstract}
Most rhizobial inoculants that stimulate legume yield are applied with carriers that enhance root contact. The physicochemical properties of biochar are suitable for microbial growth, and it could be an alternative to peat, which comes from decreasing reserves but is the commonest solid inoculant carrier. The aim of the current research was to evaluate biochars as carriers of bradyrhizobia in solid inoculant and as coatings for seeds. Biochars and peat were inoculated with Bradyrhizobium japonicum strain 532C and storage time was assessed. A seed coating system was developed using biochar, bacteria liquid culture, water, and guar gum. The viability of bacteria in the coating and in solid biochar was evaluated at $4^{\circ} \mathrm{C}$ and $21^{\circ} \mathrm{C}$. Two biochars were selected for a germination assay. Finally, greenhouse experimentation investigated the effect of biochar inoculant and seed coating on soybean growth and nutrient uptake. The storage time experiment showed that not all biochars equally sustain bacteria survival over time. The germination assay demonstrated that biochar seed coating had no effect on soybean germination. Greenhouse experimentation indicated that the effect of Pyrovac biochar on soybean growth characteristics and nutrient uptake depended on the fertilizer. The main finding was that biochar solid inoculant positively affected plant growth metrics, root characteristics, and the chemical composition of plants supplied with $\mathrm{N}$-free nutrient solution.
\end{abstract}

\section{Keywords}

Biochar, Bradyrhizobium japonicum, Glycine max, Inoculant Carrier, N-Fixation

\section{Introduction}

Under low-oxygen or anaerobic conditions, the combustion of biomass produc- 
es "biochar". It can be produced using organic wastes such as agricultural residues, sewage sludge, or wood chips. In recent years, biochar became a product of interest for carbon sequestration, as a soil amendment for crop yield improvement, and for bioremediation [1] [2]. Several properties of biochar suggest suitability as an inoculant carrier and seed-coating material. The physicochemical properties of biochar can sustain bacterial life: highly porous structure and surface area can be inhabited by bacteria and protect microorganisms from predation; high water holding capacity can prevent bacterial desiccation; reduced carbon is a potential source of energy, finally biochar can provide some mineral nutrients. Therefore, it is believed that biochar can sustain the growth and survival of bacteria over time. Carriers of rhizobia inoculum should release rhizobia into the soil [3] or root system to facilitate the symbiotic relationship with the plant. The aeration and spatial structure of biochar can ensure the easy liberation of bacteria from biochar inoculants to the environment. Furthermore, biochar production costs are usually low, it can be locally produced and easily available, and the use of it is environmentally safe. Other aspects of biochar that are important for potential applications in agriculture are the easiness of the sterilization process, inoculation, and seed coating preparation.

Although not many studies have evaluated biochar as a potential inoculant carrier, previous experiments suggest that biochar can be a suitable carrier for Pseudomonas libanensis. Głodowska et al. [4] demonstrated that phosphorus (P) mobilizing $P$. libanensis can survive in biochar inoculant up to 22 weeks. Gorelick et al. [5] investigated the use of combusted organic matter such as charcoal as carriers, and showed that a very high concentration of Brucellasuis can be sustained in a charcoal-cellophane system. It was also found that the stimulatory effect of charcoal in cellophane cultures happens during the active growth phase of the microorganisms. Beck [6] demonstrated that charcoal mixed with soil (1:3) could support the growth of rhizobia and replace commercially used peat moss. Viveganandan and Jauhri [7] also studied charcoal-soil (3:1), as well as calcium alginate and charcoal-soil-plus-calcium alginate as carriers for the phosphate-solubilizing bacteria Pseudomonas striata and Bacillus polymyxa. Their three experimental carriers supported relatively high levels of survival of bacteria.

Bradyrhizobium japonicumis a well-studied symbiotic bacterium that stimulates the formation of nodules on soybean (Glycine $\max$ L. [Merr.]) plants and is responsible for fixing (nitrogen) $\mathrm{N}_{2}$ at rates up to $300 \mathrm{~kg} / \mathrm{ha}$ [8]. This level of $\mathrm{N}_{2}$ fixation is rarely achieved, due to low root zone temperatures, high soil available $\mathrm{N}$ concentration, genetic determinants of compatibility between $B$. japonicum and the soybean host, and an inadequate population of indigenous $B$. japonicum [8]. Therefore, seed inoculation is recommended for maximum $\mathrm{N}_{2}$ fixation in soybean production. Soybean seed inoculation results in early nodulation and causes the formation of prominent nodules that cluster at the crown of the root. Seed inoculation is crucial for $\mathrm{N}_{2}$ fixation in the early stages of soybean crop de- 
velopment [9].

The ideal soybean inoculant could be applied to seeds in the early winter, when seed companies clean and bag seed for the coming growing season. It would contain high numbers of living cells at planting time. Such an inoculant would add value to the seeds and would remove the need for crop producers to manually add and mix inoculants into seed immediately prior to seeding. Past attempts to develop such an inoculant have resulted in insufficient cell counts by seeding time. There are reasons to believe that biochar will be a much more effective carrier due to its chemical and physicals properties.

The objectives of the current study were 1) to assess the viability and abundance of bacteria in biochar solid inoculant as well as biochar seed-coating over time (addressed by storage experiments), 2) to create a soybean seed coating system with biochar and B. japonicum, and 3) to evaluate the effect of the novel seed coating and biochar inoculant on soybean growth metrics (addressed by germination and greenhouse experiments).

\section{Methods and Materials}

\subsection{Sources of Biochar and Peat Moss}

For the study, four types of biochar were used: two from hardwood feedstock: Dynamotive-DM (West Lorne, Ontario, Canada) and Basque-BQ (Rimouski, Québec); and two from softwood feedstock: BlueLeaf-BL (Drummondville, Québec) and Pyrovac-PR (Saguenay, Québec). Peat moss-PM was the control inoculant carrier (PRO-MOSS TBK, Rivière-du-Loup, Québec). Biochar physical and chemical characteristics were described by Głodowska et al. [4].

\subsection{Experimental Designs}

Four types of biochar (DM, BQ, BL and PR) were tested for storability and bacterial survival, and peat moss (PM) was included as a control. Inoculated powdered biochar (stored at $21^{\circ} \mathrm{C}$ ) and seeds coated with inoculated biochar (stored at $21^{\circ} \mathrm{C}$ and $4^{\circ} \mathrm{C}$ ) were tested.

Based on the germination experiment, two biochars (DM and PR), which supported the highest rate of bacterial survival, were selected. The following treatments were evaluated: PR-coated seeds, PR-coated seeds inoculated with $B$. japonicum, DM-coated seeds, DM-coated seeds inoculated with B. japonicum, and the control (uncoated and uninoculated seeds).

For the greenhouse experiment, PR biochar was selected based on the results of the germination experiment. The following soybean seed treatments were tested: control-uncoated and uninoculated seeds, uncoated seeds inoculated with B. japonicum, PR-coated seeds, PR-coated seeds inoculated with B. japonicum, and uncoated and uninoculated seeds that were supplied with PR inoculated with $B$. japonicum applied at a rate of $5 \mathrm{t} / \mathrm{ha}$. Two sets of five pots, with three seeds in each, were prepared for each treatment. One set of pots was provided with all of the necessary nutrients (including nitrogen), by watering with com- 
plete Hoagland's solution, while another set was watered with $\mathrm{N}$-free Hoagland's solution. The experiment was arranged in a completely randomized design.

\subsection{Bradyrhizobium japonicum Culture, Inoculants Preparation and Storage Time}

Bradyrhizobium japonicum strain 532C was obtained from stock culture. Yeast Extract Mannitol (YEM) broth was prepared, $\mathrm{pH}$ adjusted to 7.0 with hydrochloric acid $(\mathrm{HCl})$, and sterilized for $20 \mathrm{~min}$ at $121^{\circ} \mathrm{C}$. Then $250 \mathrm{ml}$ of broth were inoculated aseptically with $2.5 \mathrm{ml}$ of bacterial culture. The culture kept in the darkness was incubated in a gyratory shaker for 14 days at $25^{\circ} \mathrm{C}$. Sterilized bags containing $30 \mathrm{~g}$ of tested biochar carriers (BL, PR, DM, and BQ) and peat moss (PM) as a standard inoculant carrier were inoculated with bacteria culture (1.2 $\mathrm{mL})$ in late log-phase $\left(4.9 \times 10^{9} \mathrm{CFU} / \mathrm{mL}\right)$ and mixed with $11 \mathrm{~mL}$ of sterile water to obtained the desired moisture. The $\mathrm{pH}$ of $\mathrm{PM}$ was measured and represented relatively low value of 4.93. To evaluated the survival of $B$. japonicum, the bacteria were isolated from each carrier at the beginning of the experiment (day 0), one week later, and at biweekly intervals for 37 weeks. The number of colonies per plate was counted and colony forming units per milliliter $(\mathrm{CFU} / \mathrm{mL})$ was determined with the following formula:

$$
\mathrm{CFU} / \mathrm{m}=\frac{\sum N}{P \times(1 / A) \times(1 / D)}
$$

where $N$ is the number of colonies/plate, $P$ is the number of plates, $A$ is the $\mathrm{ml}$ of aliquot, and $1 / D$ is the decimal dilution.

For the seed-coating preparation, soybean seeds were sterilized in $70 \%$ alcohol, washed twice in sterile water and dried in a laminar hood for $2 \mathrm{~h}$. Afterwards, sterilized carriers were mixed with sterile water, liquid culture of B. japonicum and guar gum under a laminar hood. The $\mathrm{pH}$ of peat moss was adjusted to 7 with sodium hydroxide $(\mathrm{NaOH})$. Each seed was dipped separately in a prepared formulation, placed in a sterile Petri plate (20 seeds/Petri plate) and left to dry under the laminar hood for $2 \mathrm{~h}$. Two sets of seeds were prepared; one set was subjected to $4^{\circ} \mathrm{C}$, while the other set was kept at $21^{\circ} \mathrm{C}$ to determine the influence of temperature on storage time. The bacteria were isolated from the seeds at the beginning of the experiment (day 0 ) and at biweekly intervals for 19 weeks.

\subsection{Effect of Biochar Seed Coating Inoculation on Germination}

An experiment was performed to determine the influence of seed coating on the soybean germination metrics. Based on high numbers of viable bacteria in the storage experiment, two biochars ( $P R$ and $D M)$ were selected for this experiment. The soybean cultivar selected for the study was Absolute RR (SeCan, Ontario, Canada). The following seed coating treatments were tested: PR-coated seeds, PR-coated seeds inoculated with $B$. japonicum, DM-coated seeds, DM-coated seeds inoculated with B. japonicum, and the control (uncoated and 
uninoculated seeds). For each treatment, 100 seeds were examined. Seeds were arranged on two layers of P8 filter papers (Fisherbrand) and soaked with five $\mathrm{mL}$ of sterile distilled water in a Petri plate (150 mm diameter). Each Petri plate contained ten seeds. All Petri plates were sealed with Parafilm and kept in a growth chamber at a constant temperature of $25^{\circ} \mathrm{C}$ and relative humidity $60 \%$ $80 \%$ in the dark for seven days. A daily germination count was performed during the seven-day period. Root length, seedling fresh weight, and seedling dry weight were recorded. Additionally, germination indicators were determined using the following formulas: Germination Percentage

$$
G P=\left(\frac{G_{a}}{G_{n}}\right) \times 100 \%
$$

where $G_{n}$ indicates the total number of experimental seeds, and $G_{a}$ indicates the number of normal germinating seeds on the seventh day; Germination Index,

$$
G I=\frac{\sum G_{t}}{D_{t}}
$$

where $G_{t}$ indicates the number of normal germinating seeds and $D_{t}$ indicates the number of germination days; Seedling Vigor Index,

$$
V I=G P \times S R L
$$

where $S R L$ indicates the seedling root length $(\mathrm{mm})$; Speed of Germination,

$$
S G=\frac{n_{1}}{d_{1}}+\frac{n_{2}-n_{1}}{d_{2}}+\cdots+\frac{n_{n}-n_{n-1}}{d_{n}}
$$

where $n_{\mathrm{i}}$ indicates the number of seeds that germinated on day $i$ and $d$ indicates the serial number of days.

\subsection{Greenhouse Experiment}

To evaluate the efficiency of biochar seed coating and B. japonicum inoculant on development and growth variables of soybean, a greenhouse experiment was conducted. For the experiment only the best performing biochar in the germination experiment $(\mathrm{PR})$ was used. Treatments were tested in sand and turface $(2: 1)$ nutrient-less medium. Plants were grown in a greenhouse at $25^{\circ} \mathrm{C}$ day $/ 20^{\circ} \mathrm{C}$ night, $16 \mathrm{~h}$ light $/ 8 \mathrm{~h}$ dark, and $60 \%$ - 80\% relative humidity. The following soybean seed treatments were tested: the control, uncoated seeds inoculated with $B$. japonicum, PR-coated seeds, PR-coated seeds inoculated with B. japonicum, uncoated seeds amended with $5 \mathrm{t} /$ ha of PR biochar inoculated with $B$. japonicum. To determine the influence of inoculated seed coating and inoculated biochar on $\mathrm{N}_{2}$ fixation and soybean nodulation, two sets of each treatment were prepared. One set was watered with complete Hoagland's solution to provide all necessary nutrients, including N. Another set of pots was watered with N-free Hoagland's solution. All treatments were replicated five times, with every pot containing five seeds. The experiment was arranged in a completely randomized design. The growth variables of interest (germination percentage, above ground 
fresh weight, above ground dry weight, plant height, leaf area, number of pods, and weight of pods) were quantified. Furthermore, the following root characteristics were measured: main root length, root fresh and dry weight, and number and weight of nodules. Samples of leaves and stems were dried in an oven at $75^{\circ} \mathrm{C}$ for $48 \mathrm{~h}$. Dried plant material was ground in a laboratory grinder and about 2 - $3 \mathrm{mg}$ were analyzed for total nitrogen (N\%), carbon (C\%) and nitrogen/carbon ratio (N/C) using an elemental analyzer (Thermo Quest NC2500, Thermo Quest, Milan, Italy).

\subsection{Statistical Analyses}

SAS System software (SAS 9.3, SAS Institute, Inc, 1999, Cary, NC, USA) was used for statistical analyses. The bacterial growth data from the storage time experiments were sorted by temperature before analysis. Generalized linear mixed models (SAS PROC GLIMMIX) were fit to the data using the DIST = GAMMA option in the MODEL statement, where the response variable was the $\log _{10} \mathrm{CFU}$ $(+1)$, and the structure of the covariance matrix was based on time (TYPE $=$ SP (POW) (Week)). The treatment means were compared to the control (peat moss) using Dunnett's test. SAS PROC GLIMMIX was used to model the final and repeated measurements of the plant growth variables. To adjust for multiple comparisons between treatment means, the LSMEANS statement and Bonferroni adjustment were used. SAS PROC SGPLOT was used with the LOESS statement to plot the nonparametric regressions.

\section{Results}

\subsection{Storage Time of B. japonicum Inoculated Biochar}

The number of viable cells were counted on day 0 , day 1 , and at biweekly intervals until 37 weeks. After 37 weeks, cells were viable in only PR and DM biochars (Figure 1(a)). The population abundance was $6.3 \log _{10} \mathrm{CFU} / \mathrm{mL}$ bacteria in PR biochar and $4.8 \log _{10} \mathrm{CFU} / \mathrm{mL}$ bacteria in DM biochar. Surprisingly, peat moss sustained the survival of bacteria for only a very short time. After four weeks, no viable cells were found in the peat carrier. A sudden decline in the population of B. japonicum was observed in BL and BQ biochars. In the case of BQ after 21 weeks of incubation, the $B$. japonicum population dropped from 5.1 $\log _{10} \mathrm{CFU} / \mathrm{mL}$ to 0 . In BL biochar the population of bacteria dropped dramatically after 9 weeks of incubation, therefore this biochar was not a suitable carrier for B. japonicum. After nine weeks of storage, no viable cells were found in this carrier.

\subsection{Storage Time of Coated and Inoculated with B. japonicum Seeds}

Viable B. japonicum cells in seed coatings were counted after one week and at biweekly intervals until 19 weeks. The results of the biochar storage time experiment were consistent with this study. Again, the biochar that maintained the 


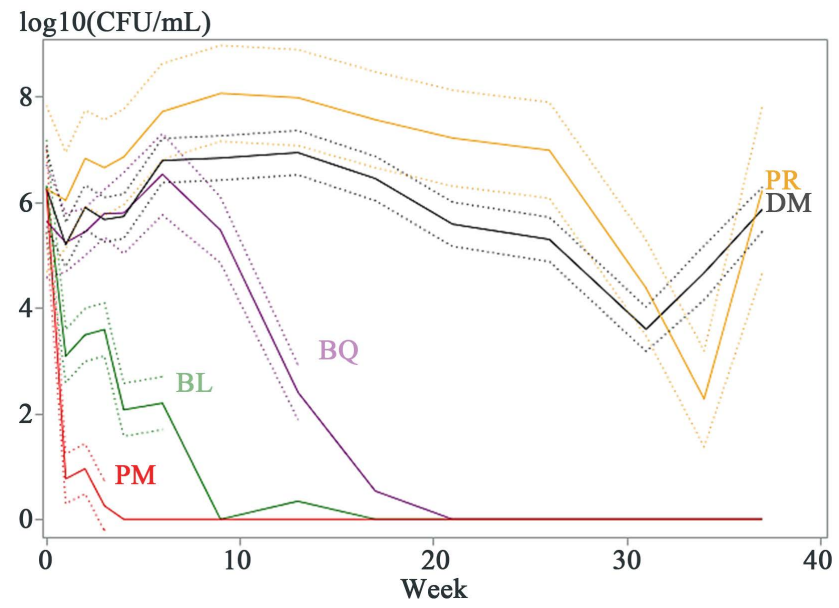

(a)

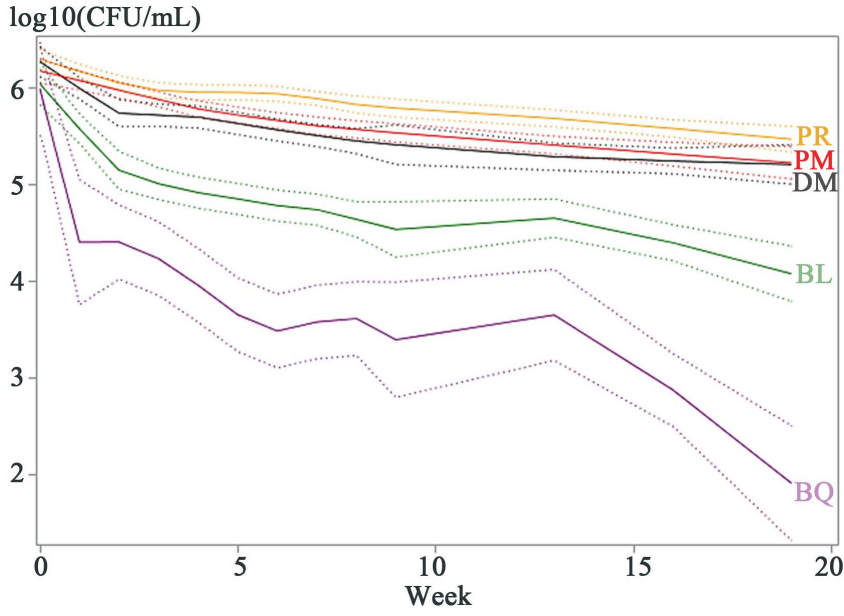

(b)

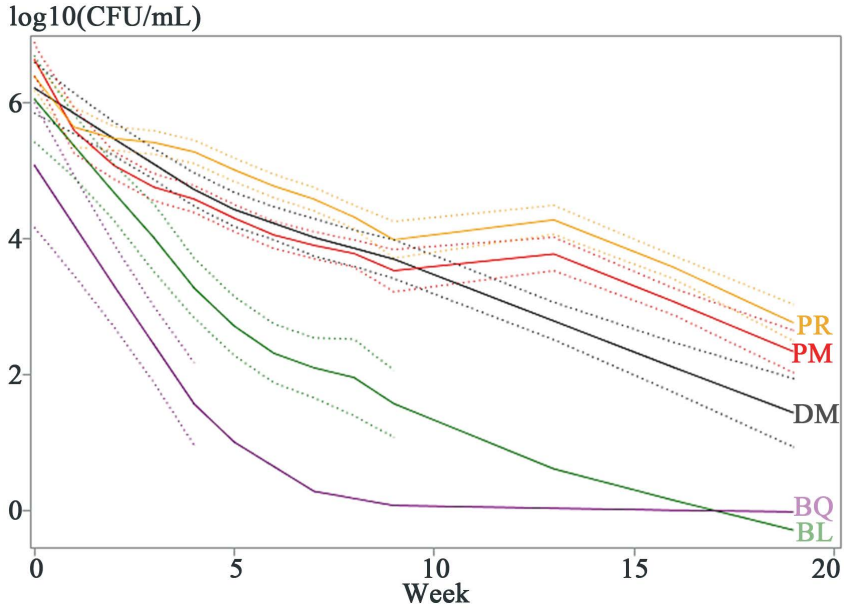

(c)

Figure 1. Nonparametric regression plots showing the $\log _{10} \mathrm{CFU} / \mathrm{ml}$ of $B$. japonicum in a powdered biochar stored at $21^{\circ} \mathrm{C}(\mathrm{a})$, inoculated biochar seed coating stored $4^{\circ} \mathrm{C}(\mathrm{b})$, and inoculated biochar seed coating stored at $21^{\circ} \mathrm{C}$ (c) as a function of time. Seed coating carriers: peat moss (PM), BlueLeaf (BL), Pyrovac (PR), Dynamotive (DM), Basque (BQ). Dotted line indicates $95 \%$ confidence limits. 
highest number of bacterial cells in the coated seeds were PR and DM. After 19 weeks, PR-coated seeds sustained $5.0 \log _{10} \mathrm{CFU} / \mathrm{mL}$ and DM-coated seeds sustained $4.9 \log _{10} \mathrm{CFU} / \mathrm{mL}$, under $4^{\circ} \mathrm{C}$ temperature conditions (Figure $1(\mathrm{~b})$ ). The temperature significantly affected the survival of bacteria over time. The population density of bacteria was significantly higher when seeds were stored at a low temperature. For example, the bacterial population declined by $62 \%$ on DM-coated seeds stored at $21^{\circ} \mathrm{C}$ (Figure $1(\mathrm{c})$ ), but when seeds were stored at $4^{\circ} \mathrm{C}$, the same treatment resulted in a decline of $22 \%$, compared to the initial bacteria population. The carrier least suitable for $B$. japonicum seed coating was $\mathrm{BQ}$ biochar. After five weeks of incubation at $21^{\circ} \mathrm{C}$, no viable cells were found. The survival of bacteria in this carrier was significantly higher at $4^{\circ} \mathrm{C}$, but the abundance of bacteria was much lower $\left(2.3 \log _{10} \mathrm{CFU} / \mathrm{mL}\right.$ after 19 weeks) than other treatments. Peat moss in the seed coating sustained bacterial abundance at a much higher level than in the previous experiment, where solid peat moss was inoculated directly. This indicated that a major limitation to the bacterial population was $\mathrm{pH}$. Once $\mathrm{pH}$ had been adjusted to neutral ( $\mathrm{pH} 7.0$ ), peat moss sustained the survival of $B$. japonicum for up to 19 weeks (at 21 and $4^{\circ} \mathrm{C}$ ) at a level similar to DM biochar, $2.5 \log _{10} \mathrm{CFU} / \mathrm{ml}$ on average at $21^{\circ} \mathrm{C}$ and $4.9 \log _{10}$ $\mathrm{CFU} / \mathrm{mL}$ at $4^{\circ} \mathrm{C}$. It can be expected that the seed coating system developed here will ensure effective nodulation of soybean plants even after four months of seed storage at $4^{\circ} \mathrm{C}$.

\subsection{Evaluation of Biochar Seed Coating and B. japonicum Inoculant on Soybean Germination}

Biochar seed coating had little effect on soybean germination, although some of germination parameters were slightly improved by biochar seed coating (Table 1). Based on the Bonferroni-adjusted limits, seeds treated with a coating containing PR biochar and B. japonicum should produce seedlings with $4 \%$ to $26 \%$

Table 1. The characteristics of soybean seedling germination and growth.

\begin{tabular}{cccccccc}
\hline & \multicolumn{3}{c}{ Germination Variables } & \multicolumn{3}{c}{ Growth Variables } \\
\cline { 2 - 8 } $\begin{array}{c}\text { Seed } \\
\text { Coating }\end{array}$ & GP & SVI & SG & GI & $\begin{array}{c}\text { Fresh } \\
\text { weight } \\
(\mathrm{g})\end{array}$ & $\begin{array}{c}\text { Root } \\
\text { Length } \\
(\mathrm{cm})\end{array}$ & $\begin{array}{c}\text { Dry } \\
\text { weight } \\
(\mathrm{g})\end{array}$ \\
\hline PR & $89.3 \pm 2.2$ & 8321.52 & 4.68 & 13.864 & $0.515 \pm 0.012 \mathrm{ab}$ & 7.65 & $0.1324 \pm 0.0022$ \\
PR + & $87.4 \pm 2.1$ & 8406.83 & 5.63 & 13.554 & $0.5492 \pm 0.013 \mathrm{a}$ & 7.79 & $0.1346 \pm 0.0022$ \\
$\begin{array}{c}\text { B. japonicum } \\
\text { DM }\end{array}$ & $84.0 \pm 1.9$ & 7384.22 & 4.54 & 12.785 & $0.479 \pm 0.011 \mathrm{~b}$ & 6.82 & $0.1346 \pm 0.0022$ \\
$\begin{array}{c}\text { DM }+ \\
\text { B. japonicum }\end{array}$ & $88.1 \pm 1.7$ & 7719.46 & 4.75 & 13.278 & $0.472 \pm 0.011 \mathrm{~b}$ & 7.11 & $0.1315 \pm 0.0021$ \\
Control & $89.3 \pm 3.9$ & 8907.06 & 4.99 & 14.154 & $0.554 \pm 0.013 \mathrm{a}$ & 7.77 & $0.1310 \pm 0.0023$ \\
\hline
\end{tabular}

Bonferroni grouping for least squares means $(\alpha=0.05)$. LS-means with the same letter are not significantly different. GP: Germination percentage, SVI: Seedling Vigor Index, SG: Speed of Germination, GI: Germination Index 
higher fresh weight than seedlings grown from seeds coated with uninoculated DM biochar, and $6 \%$ to $28 \%$ higher fresh weight than seedlings grown from seeds coated with DM biochar and inoculated with $B$. japonicum. It is expected that larger, heavier soybean seedlings will be more competitive and produce superior crop yield.

\subsection{Greenhouse Experiment}

The soybean growth characteristics (Table 2) indicated that, when plants were watered with complete Hoagland's solution, no effect on soybean growth was detected due to the experimental treatments. The characteristics of roots (Table 3 ) of the plants that were supplied with complete Hoagland's solution were consistent with above ground plant characteristics. Where $\mathrm{N}$ was supplied, the experimental inoculation and biochar treatments did not affect soybean roots. Furthermore, where $\mathrm{N}$ was supplied, nodules were scarce on the roots of inoculated plants. PR coated seeds inoculated with $B$. japonicum produced on average 4.2 nodules/plant, while seeds inoculated but not coated with biochar produced 3.1 nodules/plant.

Chemical analysis of soybean tissue was performed to investigate the influence of seed coating and biochar inoculant on basic uptake of elements (Table 4). Although a numerically higher N\% was observed for the control plants, there was no statistically significant difference across the treatments of soybean plants supplied with complete Hoagland's solution. Similarly, no statistical difference in $\mathrm{C} \%$ was found, as expected because $\mathrm{C}$ is a very consistent product of photosynthesis.

Table 2. The growth characteristics of soybean plants.

\begin{tabular}{|c|c|c|c|c|c|c|c|c|}
\hline \multirow{2}{*}{$\begin{array}{c}\text { Seed } \\
\text { Coating }\end{array}$} & \multicolumn{8}{|c|}{ Growth characteristics } \\
\hline & $\begin{array}{l}\text { Plant Fresh } \\
\text { Weight (g) }\end{array}$ & $\begin{array}{l}\text { Plant Height } \\
(\mathrm{cm})\end{array}$ & $\begin{array}{c}\text { Pod } \\
\text { Number }\end{array}$ & $\begin{array}{c}\text { Leaf } \\
\text { Number }\end{array}$ & $\begin{array}{l}\text { Leaf Area } \\
\left(\mathrm{cm}^{2}\right)\end{array}$ & $\begin{array}{l}\text { Plant Dry } \\
\text { Weight (g) }\end{array}$ & $\begin{array}{c}\text { Pod Fresh } \\
\text { Weight (g) }\end{array}$ & $\begin{array}{c}\text { Pod Dry } \\
\text { Weight (g) }\end{array}$ \\
\hline \multicolumn{9}{|c|}{ + Complete Hoagland's solution } \\
\hline Uncoated & 3.70 & 57.61 & $2.5 \pm 0.4 \mathrm{a}$ & $13.9 \pm 1.0 \mathrm{a}$ & 152.00 & $1.36 \pm 0.08 \mathrm{a}$ & $0.52 \pm 0.09 \mathrm{a}$ & $0.113 \pm 0.017 a$ \\
\hline $\mathrm{PR}$ & 3.79 & 59.67 & $2.5 \pm 0.4 \mathrm{a}$ & $14.0 \pm 1.0 \mathrm{a}$ & 154.04 & $1.30 \pm 0.08 \mathrm{a}$ & $0.66 \pm 0.11 \mathrm{a}$ & $0.122 \pm 0.019 \mathrm{a}$ \\
\hline B. japonicum & 4.01 & 68.27 & $2.5 \pm 0.4 \mathrm{a}$ & $15.9 \pm 1.0 \mathrm{a}$ & 156.01 & $1.43 \pm 0.09 \mathrm{a}$ & $0.66 \pm 0.12 \mathrm{a}$ & $0.128 \pm 0.021 \mathrm{a}$ \\
\hline $\mathrm{PR}+$ B. japonicum & 3.71 & 74.02 & $2.7 \pm 0.4 \mathrm{a}$ & $14.2 \pm 1.0 \mathrm{a}$ & 146.85 & $1.39 \pm 0.08 \mathrm{a}$ & $0.38 \pm 0.06 \mathrm{a}$ & $0.080 \pm 0.011 \mathrm{a}$ \\
\hline \multicolumn{9}{|c|}{ + Nitrogen-free Hoagland's solution } \\
\hline Uncoated & 1.51 & 49.87 & $1.1 \pm 0.3 \mathrm{~b}$ & $6.1 \pm 0.6 b$ & 39.11 & $0.48 \pm 0.04 b$ & $0.35 \pm 0.07 b$ & $0.069 \pm 0.012 b$ \\
\hline $\mathrm{PR}$ & 1.41 & 50.98 & $0.8 \pm 0.2 b$ & $6.9 \pm 0.7 b$ & 39.05 & $0.47 \pm 0.04 b$ & $0.13 \pm 0.03 c$ & $0.0322 \pm 0.007 b$ \\
\hline B. japonicum & 3.93 & 76.91 & $3.2 \pm 0.5 \mathrm{a}$ & $16.2 \pm 1.0 \mathrm{a}$ & 181.93 & $1.3 \pm 0.10 \mathrm{a}$ & $0.76 \pm 0.12 \mathrm{a}$ & $0.155 \pm 0.021 a$ \\
\hline $\mathrm{PR}+$ B. japonicum & 3.54 & 56.86 & $3.3 \pm 0.4 \mathrm{a}$ & $14.4 \pm 1.0 \mathrm{a}$ & 185.62 & $1.12 \pm 0.09 \mathrm{a}$ & $0.76 \pm 0.11 \mathrm{a}$ & $0.147 \pm 0.019 a$ \\
\hline $\begin{array}{c}\text { Uncoated }+\mathrm{PR}+ \\
\text { B. japonicum }\end{array}$ & 3.91 & 57.07 & $3.0 \pm 0.4 a$ & $15.4 \pm 1.0 \mathrm{a}$ & 197.97 & $1.24 \pm 0.10 \mathrm{a}$ & $0.64 \pm 0.10 \mathrm{ab}$ & $0.133 \pm 0.018 a$ \\
\hline
\end{tabular}

Bonferroni grouping for least squares means $(\alpha=0.05)$ was used for comparisons within each nitrogen treatment group. LS-means with the same letter are not significantly different. 
Table 3. The root characteristics of soybean plants.

\begin{tabular}{|c|c|c|c|c|c|}
\hline \multirow[b]{2}{*}{ Seed Coating } & \multicolumn{5}{|c|}{ Root characteristics } \\
\hline & $\begin{array}{l}\text { Root Fresh } \\
\text { Weight (g) }\end{array}$ & $\begin{array}{l}\text { Nodules } \\
\text { per Plant }\end{array}$ & $\begin{array}{l}\text { Nodule Fresh } \\
\text { Weight (g) }\end{array}$ & $\begin{array}{l}\text { Nodule Dry } \\
\text { Weight (g) }\end{array}$ & $\begin{array}{c}\text { Root Dry } \\
\text { Weight (g) }\end{array}$ \\
\hline \multicolumn{6}{|c|}{ + Complete Hoagland's solution } \\
\hline Uncoated & 3.86 & $0.0 \pm 0.0 \mathrm{a}$ & $0.00000 \pm 0.00156 c$ & $0.0000 \pm 0.0003 b$ & $0.500 \pm 0.038 \mathrm{ab}$ \\
\hline PR & 4.13 & $0.0 \pm 0.0 \mathrm{a}$ & $0.00000 \pm 0.00156 c$ & $0.0000 \pm 0.0003 b$ & $0.586 \pm 0.048 b$ \\
\hline B. japonicum & 3.80 & $3.1 \pm 0.6 \mathrm{a}$ & $0.02745 \pm 0.00456 \mathrm{~b}$ & $0.0078 \pm 0.0008 \mathrm{a}$ & $0.490 \pm 0.037 \mathrm{ab}$ \\
\hline $\mathrm{PR}+$ B. japonicum & 3.38 & $4.2 \pm 0.7 \mathrm{a}$ & $0.04273 \pm 0.00285 \mathrm{a}$ & $0.0087 \pm 0.0005 \mathrm{a}$ & $0.415 \pm 0.029 \mathrm{a}$ \\
\hline \multicolumn{6}{|c|}{ + Nitrogen-free Hoagland's solution } \\
\hline Uncoated & 2.11 & $0.83 \pm 0.28 c$ & $0.035 \pm 0.020 c$ & $0.006 \pm 0.004 \mathrm{~b}$ & $0.285 \pm 0.026 \mathrm{ab}$ \\
\hline PR & 2.26 & $0.92 \pm 0.30 c$ & $0.031 \pm 0.020 c$ & $0.004 \pm 0.003 b$ & $0.222 \pm 0.018 \mathrm{a}$ \\
\hline B. japonicum & 2.89 & $19.42 \pm 2.67 \mathrm{ab}$ & $0.514 \pm 0.028 \mathrm{a}$ & $0.106 \pm 0.006 \mathrm{a}$ & $0.323 \pm 0.032 \mathrm{ab}$ \\
\hline $\mathrm{PR}+$ B. japonicum & 2.84 & $15.25 \pm 2.16 \mathrm{~b}$ & $0.410 \pm 0.022 b$ & $0.086 \pm 0.004 \mathrm{a}$ & $0.334 \pm 0.033 b$ \\
\hline Uncoated $+\mathrm{PR}+B$. japonicum & 2.96 & $29.58 \pm 3.91 \mathrm{a}$ & $0.508 \pm 0.029 \mathrm{ab}$ & $0.103 \pm 0.005 a$ & $0.379 \pm 0.040 \mathrm{~b}$ \\
\hline
\end{tabular}

Bonferroni grouping for least squares means $(\alpha=0.05)$ was used for comparisons within each nitrogen treatment Group. LS-means with the same letter are not significantly different.

Table 4. Chemical composition of soybean plants.

\begin{tabular}{|c|c|c|c|}
\hline \multirow{2}{*}{ Seed Coating } & \multicolumn{3}{|c|}{ Chemical composition } \\
\hline & $\mathrm{N} \%$ & $\mathrm{C} \%$ & $\mathrm{~N} / \mathrm{C}$ \\
\hline \multicolumn{4}{|c|}{ + Complete Hoagland's solution } \\
\hline Uncoated & $2.9 \pm 0.7$ & $44.3 \pm 2.0$ & $0.0270 \pm 0.0008 \mathrm{a}$ \\
\hline $\mathrm{PR}$ & $2.5 \pm 0.6$ & $43.9 \pm 2.0$ & $0.0229 \pm 0.0011 b$ \\
\hline B. japonicum & $2 . .5 \pm 0.6$ & $44.1 \pm 2.0$ & $0.0240 \pm 0.0008 \mathrm{ab}$ \\
\hline $\mathrm{PR}+B$. japonicum & $2.3 \pm 0.6$ & $43.9 \pm 2.0$ & $0.0222 \pm 0.0007 \mathrm{~b}$ \\
\hline \multicolumn{4}{|c|}{ + Nitrogen-free Hoagland's solution } \\
\hline Uncoated & $2.0 \pm 0.6$ & $41.3 \pm 2.0$ & $0.0180 \pm 0.0014 \mathrm{c}$ \\
\hline PR & $1.8 \pm 0.5$ & $40.5 \pm 2.0$ & $0.0173 \pm 0.0016 \mathrm{c}$ \\
\hline B. japonicum & $3.7 \pm 0.8$ & $44.6 \pm 2.0$ & $0.0342 \pm 0.0009 \mathrm{~b}$ \\
\hline $\mathrm{PR}+$ B. japonicum & $3.8 \pm 0.8$ & $44.4 \pm 2.0 \mathrm{a}$ & $0.0360 \pm 0.0010 \mathrm{ab}$ \\
\hline Uncoated $+\mathrm{PR}+$ B. japonicum & $4.4 \pm 0.8$ & $44.5 \pm 2.0 \mathrm{a}$ & $0.0406 \pm 0.0011 \mathrm{a}$ \\
\hline
\end{tabular}

Bonferroni grouping for least squares means $(\alpha=0.05)$ was used for comparisons within each nitrogen treatment group. LS-means with the same letter are not significantly different.

Changes in soybean growth parameters (Table 2) were observed for plants supplied with $\mathrm{N}$-free Hoagland solution, and the main source of variation was the B. japonicum inoculant. The fresh weight of plants improved significantly for all inoculated seed treatments. Based on the Bonferroni-adjusted limits at 95\% confidence, seed coating with PR and inoculating with B. japonicum would 
increase plant fresh weight by $74 \%$ to $216 \%$ compared to the control. Similarly, inoculation improved soybean dry weight to a statistically significant degree. It was found that seed coating with PR and inoculating with $B$. japonicum would result in $68 \%$ to $224 \%$ higher plant dry weight than controls.

The experimental plants were significantly taller when seeds were inoculated. More pods were produced where the treatment included inoculation with $B$. japonicum. The fresh weight and dry weight of pods were higher when seeds were coated with PR biochar and inoculated with B. japonicum, compared to uncoated seeds supplied with inoculated biochar. Based on Bonferroni-adjusted limits at $95 \%$ confidence, the mean pod fresh weight of plants grown from PR-coated seed would be $92 \%$ to $61 \%$ lower than plants grown from PR-coated seed inoculated with $B$. japonicum. The number of trifoliate leaves and the total leaf area were higher for inoculated plants.

Variation in root characteristics (Table 3) were observed in plants watered with $\mathrm{N}$-free Hoagland's solution. Inoculated seeds produced more nodules than uninoculated seeds. Uncoated seeds supplied with inoculated PR biochar ( $5 \mathrm{t} / \mathrm{ha}$ ) produced on average 29.6 nodules/plant, $34 \%$ more than uncoated but inoculated seeds. Based on the Bonferroni-adjusted limits at 95\% confidence, the mean number of nodules of plants grown from PR-coated seed would be $98 \%$ to $83 \%$ less than PR-coated seed inoculated with B. japonicum. The fresh and dry weight of nodules was highest when uncoated seeds were supplied with solidbiochar inoculant, however, there was no statistically significant difference across other treatments that included B. japonicum inoculation.

Plants grown from inoculated seeds (that were subsequently supplied with $\mathrm{N}$-free Hoagland's solution) showed a significant increase in N\% compared to plants grown from uninoculated seed (Table 4). The highest N\% was recorded for plants grown from seeds that were treated with PR biochar that was inoculated with $B$. japonicum, which was 4.35 . Inoculation with $B$. japonicum also increased the carbon content $(\mathrm{C} \%)$ of soybean plants. The N/C ratio improved significantly for the inoculated treatments. The application of inoculated biochar caused a statistically significant increase in N/C compared to other treatments that involved B. japonicum.

\section{Discussion}

\subsection{Storage Time of B. japonicum Inoculated Biochar and Biochar Seed-Coating}

PR and DM biochars were the most appropriate carriers to host B. japonicum. Mubarik et al. [10] reported that the optimal $\mathrm{pH}$ condition for $B$. japonicum growth is between 6 and 7, although a lower optimum may be found for strains isolated from soils of more acidic $\mathrm{pH}$. The survival of applied rhizobia is limited by low soil $\mathrm{pH}$ and high soil temperatures in many tropical soils [11]. These results confirm that the low $\mathrm{pH}$ is a factor of the limited bacterial viability over time in the peat moss ( $\mathrm{pH} 4.93)$ carrier. On the other hand, the $\mathrm{pH}(\mathrm{pH} 8.59)$ of 
BL biochar could be too high for B. japonicum, and this carrier supported cell viability for only nine weeks at a relatively low abundance (Figure 1(a)). The PR biochar was characterized by elevated total pore area $\left(17.32 \mathrm{~m}^{2} / \mathrm{g}\right)$, which was higher than for peat moss and BL biochar. DM biochar was also characterized by higher total pore area $\left(13.36 \mathrm{~m}^{2} / \mathrm{g}\right)$. Also, the porosity of these carriers is practically equivalent, the porosity of PR biochar was $78.2 \%$ and the porosity of DM biochar was $78.5 \%$, while the porosity of peat moss was $83.3 \%$ and the porosity of BL biochar was $89.9 \%$. The porosity characteristics of the best and worst carriers suggested that these might be the factors that affect the bacterial abundance. Quilliam et al. [12] demonstrated that biochar colonization is a long process that required significant amount of time ( $>100$ years). In their study, it was shown that, after three years in the soil, only very a small portion of biochar pieces was occupied by bacteria. Furthermore, it was suggested that most bacterial cells, as well as fungal hyphae, cannot penetrate pores $<1 \mu \mathrm{m}$ in size, in which case $17.5 \%$ of the total pore volume of biochar in their study was uninhabitable. While the porosity of biochar varies, depending on the feedstock and pyrolysis process, the average pore diameter of DM biochar was $0.68 \mu \mathrm{m}$, and the average pore diameter of PR biochar was $0.49 \mu \mathrm{m}$, so it can be assumed that these biochars provide a suitable habitat for bacteria.

Okereke and Okeho [13] performed a short-term experiment on three Bradyrhizobium strains. Their study evaluated the suitability of rice husk, charcoal, and coal as inoculant carriers. The results revealed that the most effective carrier was rice husk, which sustained 5.8 to $7.5 \log _{10} \mathrm{CFU} / \mathrm{mL}$ of bacteria after six weeks of incubation at $26^{\circ} \mathrm{C}$. Our results show that the PR biochar is much more effective, since the average abundance after 37 weeks was $6.3 \log _{10} \mathrm{CFU} / \mathrm{mL}$. Khavazi et al. [14] assessed the effects of different carrier, sterilization techniques, and incubation times on survival of $B$. japonicumin soybean inoculants. The results of their study showed that bacterial populations were greatest after 180 days of incubation $\left(9 \log _{10} \mathrm{CFU} / \mathrm{g}\right)$ in perlite-based carrier. The experimental data from our study indicated that the population of $B$. japonicumin PR biochar was slightly lower. Our shelf life experiment, however, lasted 80 days longer than the experiment reported by Khavazi et al. [14].

A slow decline in B. japonicum population, of one order of magnitude with respect to the initial population, was observed when the coated and inoculated seed were stored $4^{\circ} \mathrm{C}$. Over 4 months after inoculation, the viable-cell count was sufficiently high to ensure good nodulation ( $6 \log _{10}$ bacteria/seed) when the PR, $\mathrm{DM}$ and PM carriers were used. The storage temperature influenced the survival of bacteria on the seed coat. Temprano et al. [15] reported that, in the case of peat and vermiculite carriers, the survival of rhizobia was higher when stored at $4^{\circ} \mathrm{C}$ than at $28^{\circ} \mathrm{C}$, which agrees with the results of our study. As it was previously explained by Gaind and Gaur [16], low temperatures (from $4^{\circ} \mathrm{C}$ to $10^{\circ} \mathrm{C}$ ) slow down the multiplication of cells and decrease metabolic processes, thus the nutrient depletion is usually much slower. Therefore, it was expected that bacterial 
abundance would be higher under lower temperature conditions. It was also expected that the $B$. japonicum population would be significantly lower in seed coating, compared to powdered biochar. This is probably due to the reduced moisture of the seed coating, which was dried for two hours under a laminar hood before storage to prevent premature germination of soybean seeds. In the end, the density of $B$. japonicumin the PR seed coating was sufficient to inoculate soybean seeds and meet the recommended doses of $5-6 \log _{10}$ rhizobia/seed [17].

\subsection{Greenhouse Experiment}

\subsubsection{Plants Supplied with Complete Hoagland's Solution}

Many studies have been performed to assess the effect of $\mathrm{N}$ fertilizer on biological N-fixation. The negative impact of nitrate in the soil solution on the $\mathrm{N}_{2}$ fixation process in the nodules leads to serious limitations to the overall $\mathrm{N}$ uptake by the plant [18]. The majority of studies evaluating the effect of $\mathrm{N}$-fertilizer on soybean growth and $\mathrm{N}_{2}$ fixation by symbiotic bacteria show that, generally, fertilization causes a reduction in $\mathrm{N}$ fixation, due to reduced number, weight, and activity of nodules [19] [20]. The results obtained in our study clearly show that $\mathrm{N}_{2}$-fixation was influenced by the application of $\mathrm{N}$-fertilizer. Nodule number and nodule weight decreased significantly, when the soybean plants were supplied with complete Hoagland's solution, compared to the plants grown in the absence of nitrate. This agrees with the study of Albareda et al. [21], who demonstrated that the addition of $\mathrm{N}$-fertilizer to inoculated soybean plants did not increase seed yields, compared with inoculation. Furthermore, the addition of 50 $\mathrm{kg} \mathrm{N} / \mathrm{ha}$ at the beginning of the flowering stage of plant development resulted in a reduction of nodulation in inoculated plants. Research by Hungria et al. [22] revealed that the early application of small amounts of $\mathrm{N}$ results in a temporary interruption in nodule formation and generally decreases their activity. In our study, the application of $\mathrm{N}$ fertilizer reduced the effect of $B$. japonicum inoculant. Therefore, nodule fresh weight, root dry weight, and the N/C ratio of plant tissue differed between inoculated and uninoculated seeds. These experimental results suggest that, when seeds are inoculated with rhizobia, supplementation with mineral $\mathrm{N}$ is unnecessary and economically undesirable, as the effect of bacteria-plant symbiosis is suppressed.

\subsubsection{Plants Supplied with N-Free Hoagland's Solution}

There is no doubt about the positive effect of rhizobium inoculants on soybean growth where $\mathrm{N}$-fertilizer is lacking. Kubota et al. [23] demonstrated that use of peat moss as a carrier for commercially available B. japonicum inoculant increased plant shoot dry weight and nodule dry weight. The strain for inoculation should be chosen carefully. Okereke and Okeh [13] demonstrated the influence of four different $B$. japonicumstrains on cowpea. Although all of their strains increased cowpea plant growth and total $\mathrm{N}$ concentration, some differences between strains were found. Moreover, the experiment was performed in sandy 
and silty soils, which can affect inoculant efficiency. Therefore, it is strongly recommended to select the inoculant that is suitable for the crop and soil type.

The results of our study confirm the positive effect of inoculation on soybean growth. Although there is no significant difference between the experimental methods of inoculation, generally, the method can affect plant growth. The nodulation process was significantly improved for the inoculated plants. Higher nodule number and nodule weight may indicate that, during later growth, such plants will be capable of more efficient $\mathrm{N}$-fixation and it is expected that final yield will be higher, compared to plants with lower nodule numbers. Albareda et al. [21] found that the soybean plants with more nodules and higher dry weight of nodules produce more pods and higher seed yields. The results of our study, of plants supplied with complete nutrient solution and $\mathrm{N}$-free solution, suggest that seed inoculation by seed-coating, as well as direct application of inoculated biochar, can increase nodulation. Soybean $\mathrm{N}$ demand can be met byN $\mathrm{N}_{2}$ fixation that leads to improved biomass production. Although, the methods of inoculation were different for uncoated seeds and biochar coated seeds, it must be considered that the seeds used in this experiment were inoculated one day prior to seeding, therefore the levels of abundance of bacteria, with either coated or uncoated seed, were similar. It can be expected that, after three months of storage, the bacterial population on uncoated seeds will decline due to desiccation and a lack of protection and nutrients, and therefore uncoated seeds will not be able to ensure soybean nodulation.

\section{Conclusions}

The capacity of $B$. japonicum to supply the soybean $\mathrm{N}$ demand and significantly reduce $\mathrm{N}$ fertilizer application has resulted in rhizobial inoculants appearing on the market [24], but the quality and efficiency of these products is often in doubt. In the current study, biochar was used as an inoculant carrier for B. japonicum as an alternative to peat moss. A seed coating system was developed that permits the maintenance of a high population of $B$. japonicum for over four months, while biochar-based inoculant maintained a high population of B. japonicum for another five months, which can ensure the efficient nodulation of soybean. The current investigation demonstrated that the chemical and physical properties of biochars strongly affect the survival of bacteria over time. Out of five inoculated carriers, only two (PR and DM) created suitable conditions to support the viability of bacteria for approximately nine months. It is hypothesized that the chemical composition and porosity of the biochar were factors that contributed to bacterial viability. By adjusting the $\mathrm{pH}$ of peat moss, it was demonstrated that $\mathrm{pH}$ was an important factor that limits bacterial viability.

A germination experiment revealed that seed coating with biochar did not inhibit soybean germination. A greenhouse experiment showed that the application of $\mathrm{N}$ fertilizer significantly affects the efficacy of the inoculant. These results support previous studies and show that nitrate application decreases the nodula- 
tion process and reduces the number of nodules. When complete Hoagland's solution was provided to soybean plants, the effect of inoculation was not significant. On the other hand, when plants were supplied with N-free Hoagland's solution differences in plant growth metrics, root characteristics and chemical composition were found. Clearly, B. japonicum inoculation was the main cause of variation; it improved plant growth and the uptake of some nutrients. It was observed that application of inoculated biochar increased the nodulation of soybean. This strongly suggests that, in later development stages, such plants would benefit from higher $\mathrm{N}$ availability. Further experimentation under field conditions will be necessary to explore this hypothesis.

\section{Acknowledgements}

This research was funded by Blue Leaf Inc. and NSERC (CRDPJ 39818). Special thanks to Dr. Fazli Mabood for sharing information and methods related to bacteria growth and inoculation.

\section{References}

[1] Chen, B., Yuan, M. and Qian, L. (2012) Enhanced Bioremediation of PAHsContaminated Soil by Immobilized Bacteria with Plant Residue and Biochar as Carriers. Journal of Soils and Sediments, 12, 1350-1359. https://doi.org/10.1007/s11368-012-0554-5

[2] Freddo, A., Cai, C. and Reid, B. (2012) Environmental Contextualisation of Potential Toxic Elements and Polycyclic Aromatic Hydrocarbons in Biochar. Environmental Pollution. 171, 18-24. https://doi.org/10.1016/j.envpol.2012.07.009

[3] Smith, R.S. (1992) Legume Inoculant Formulation and Application. Canadian Journal of Microbiology, 38, 485-492. https://doi.org/10.1139/m92-080

[4] Głodowska, M., Husk, B., Schwinghamer, T. and Smith, D.L. (2016) Biochar Is a Growth-Promoting Alternative to Peat Moss for the Inoculation of Corn with a Pseudomonad. Agronomy for Sustainable Development, 36, 21. https://doi.org/10.1007/s13593-016-0356-Z

[5] Gorelick, A.N., Mead, D.D. and Kelly, M.H. (1951) The Growth of Bacteria in a Charcoal-Cellophane System. (ISO 4). Journal of Bacteriology, 61, 507-513.

[6] Beck, D.P. (1991) Suitability of Charcoal-Amended Mineral Soil as Carrier for Rhizobium Inoculants. Soil Biology and Biochemistry, 23, 41-44.

https://doi.org/10.1016/0038-0717(91)90160-L

[7] Viveganandan, G. and Jauhri, K.S. (2000) Growth and Survival of Phosphate-Solubilizing Bacteria in Calcium Alginate. Microbiological Research, 155, 205-207. https://doi.org/10.1016/S0944-5013(00)80033-6

[8] Keyser, H.H. and Li., F. (1992) Potential for Increasing Biological Nitrogen Fixation in Soybean. In: Biological Nitrogen Fixation for Sustainable Agriculture, Springer, Netherlands, 119-135. https://doi.org/10.1007/978-94-017-0910-1_7

[9] Daramola, D.S., Danso, K.A. and Hardarson, G. (1994) Nodulation, N2, Fixation and Dry Matter Yield of Soybean [Glycine max (L.) Merrill] Inoculated with Effective and Ineffective Bradyrhizobium japonicum Strains. Soil Biology and Biochemistry, 26, 883-889. https://doi.org/10.1016/0038-0717(94)90304-2 
[10] Mubarik, N.R., Habibah, H. and Wahyudi, A.T. (2012) Greenhouse Experiments of Symbiotic Effectiveness of Acid-Aluminium Tolerance Bradyrhizobium japonicum Strains on Soybean Plant. International Conference on Applied Life Sciences, Turkey, 10-12 September 2012, 244-249.

[11] Danso, S.K.A. and Owiredu, J.D. (1988) Competitiveness of Introduced and Indigenous Cowpea Bradyrhizobium Strains for Nodule Formation on Cowpeas [ Vignaunguiculata (L.) Walp] in Three Soils. Soil Biology and Biochemistry, 20, 305-310.

[12] Quilliam, R.S., Glanville, H.C., Wade, S.C. and Jones, D.L. (2013) Life in the "Charosphere"-Does Biochar in Agricultural Soil Provide a Significant Habitat for Microorganisms? Soil Biology and Biochemistry, 65, 287-293.

[13] Okereke, G.U. and Okeho, O.C. (2007) Survival of Cowpea Bradyrhizobia in Carrier Materials and Inoculation Response in Soil. African Crop Science Journal, 8, 1183-1186.

[14] Khavazi, K., Rejali, F., Seguin, P. and Miransari, M. (2007) Effects of Carrier, Sterilisation Method, and Incubation on Survival of Bradyrhizobium japonicum in Soybean (Glycine max L.) Inoculants. Enzyme and Microbial Technology, 41, 780-784.

[15] Temprano, F., Albareda, M., Camacho, M., Daza, A., Santamaria, C. and Rodríguez-Navarro, N.D. (2002) Survival of Several Rhizobium/Bradyrhizobium Strains on Different Inoculant Formulations and Inoculated Seeds. International Microbiology, 5, 81-86. https://doi.org/10.1007/s10123-002-0067-y

[16] Gaind, S. and Gaur, A.C. (1990) Shelf Life of Phosphate-Solubilizing Inoculants as Influenced by Type of Carrier, High Temperature and Low Moisture. Canadian Journal of Microbiology, 36, 846-849. https://doi.org/10.1139/m90-146

[17] Lupyawi, N.Z., Olsen, P.E., Sande, E.S., Keyser, H.H., Collins, M.M., Singleton, P. and Rice, W.A. (2000) Inoculant Quality and Its Evaluation. Field Crops Research, $65,259-270$.

[18] Salvagiotti, F., Cassman, K.G., Specht, J.E., Walters, D.T., Weiss, A. and Doberman, A. (2008) Nitrogen Uptake, Fixation, and Response to Fertilizer N in Soybeans: A Review. Field Crops Research, 108, 1-13.

[19] Starling, M.E., Wood, C. and Weaver, D.B. (1998) Starter Nitrogen and Growth Habit Effects on Late-Planted Soybean. Agronomy Journal, 90, 658-662. https://doi.org/10.2134/agronj1998.00021962009000050015x

[20] Chen, Z., Mackenzie, A.F. and Fanous, M.A. (1992) Soybean Nodulation and Grain Yield as Influenced by N-Fertilizer Rate, Plant Population Density and Cultivar in South Quebec. Canadian Journal of Plant Science, 72, 1049-1056. https://doi.org/10.4141/cjps92-131

[21] Albareda, M., Rodriguez-Navarro, D.N. and Temprano, F.J. (2009) Soybean Inoculation: Dose, N Fertilizer Supplementation and Rhizobia Persistence. Field Crops Research, 113, 352-356.

[22] Hungria, M., Franchini, J., Campo, R. and Graham, P. (2005) The Importance of Nitrogen Fixation to Soybean Cropping in South America. In: Werner, D. and Newton, W., Ed., Nitrogen Fixation in Agriculture, Forestry, Ecology, and the Environment, Springer, Berlin, 25-42. https://doi.org/10.1007/1-4020-3544-6_3

[23] Kubota, A., Hoshiba, H. and Bordon, J. (2008) Effect of Fertilizer-N Application and Seed Coating with Rhizobial Inoculants on Soybean Yield in Eastern Paraguay. RevistaBrasileira de Ciência do Solo, 32, 1627-1633. https://doi.org/10.1590/S0100-06832008000400027 
[24] Benrebah, F.B., Prévost, D., Yezza, A. and Tyagi, R.D. (2007) Agro-Industrial Waste Materials and Wastewater Sludge for Rhizobial Inoculant Production: A Review. Bioresource Technology, 98, 3535-3546.

Submit or recommend next manuscript to SCIRP and we will provide best service for you:

Accepting pre-submission inquiries through Email, Facebook, LinkedIn, Twitter, etc. A wide selection of journals (inclusive of 9 subjects, more than 200 journals)

Providing 24-hour high-quality service

User-friendly online submission system

Fair and swift peer-review system

Efficient typesetting and proofreading procedure

Display of the result of downloads and visits, as well as the number of cited articles Maximum dissemination of your research work

Submit your manuscript at: http://papersubmission.scirp.org/

Or contact as@scirp.org 